\title{
ザンセートを利用した廃水中の $\mathrm{Cd}^{2+}$ イオンの 浮上分離についで
}

\author{
下飯坂潤三 ${ }^{1}$ 長谷部茂 \\ 松 岡 功 ${ }^{3}$ 高橋 知 行 $^{4}$ \\ 山 本 和 正 $^{5}$
}

\section{1. 緒言}

数年前, 富山県神通川流域で発生した“イタイイタイ 病は神通川上流にある神岡鉱山から排出される $\mathrm{Cd}^{2+} イ$ オンにその原因があるとされ，大きな公害問題として注 目された1”。

$\mathrm{Cd}$ は $\mathrm{Zn}$ と化学的性質が類似しており，自然界には ほぼ一定比率で存在している。したがつて， $\mathrm{Zn}^{2+}$ イオ ンの含まれる鉱山廃水汇は $\mathrm{Cd}^{2+}$ イオンも含まれている。

鉱山廃水中に含まれる $\mathrm{Fe}^{2+}, \mathrm{Zn}^{2+}$ イオンなどの有害 金属イオンは一般に消石灰を投入し，金属水酸化物とし て沈殿除去されているが, 水酸化カドミウムの溶解度積 注第 1 表傜すように比較的大きく, $\mathrm{Cd}^{2+}$ イオンの濃度 をかなり低い許容濃度まで下げるためには, 多量の消石 灰を必要とし，また殿物の沈降容積も大きくなるため, 経済的に大きな負担になってくるとともに，Znの再溶 解, 高 $\mathrm{pH}$ の処理水を選鉱用水などにそのまま使用する ことが困難であるなど，不利な面が多い。

向井・古屋仲はこのような廃水中の微量の $\mathrm{Cd}^{2+}$ およ び $\mathrm{Zn}^{2+}$ イオンを硫化物として沈殿させた後, オクタデ シルアミンアセテートを捕収剤として浮上分離する方法 にういて検討を行なつている2”。この方法は处理水中の $\mathrm{Cd}^{2+}$ イオン濃度を極めて低濃度まで低下させ得るという

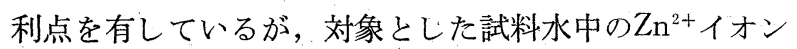
と $\mathrm{Cd}^{2+}$ イオンの濃度が余り変らない場合について報告 されており, $\mathrm{Zn}^{2+}$ イオンに比してCd ${ }^{2+}$ イオン濃度が小な る場合については更に検討が残されていると思われる。

第 1 表 金属水酸化物の溶解度積

\begin{tabular}{l|cccc}
\hline 金属水酸化物 & $\mathrm{Fe}(\mathrm{OH})_{3}$ & $\mathrm{Fe}(\mathrm{OH})_{2}$ & $\mathrm{Zn}(\mathrm{OH})_{2}$ & $\mathrm{Cd}(\mathrm{OH})_{2}$ \\
\hline 溶解度積 & $3.8 \times 10^{-38}$ & $4.8 \times 10^{-16}$ & $1.3 \times 10^{-17}$ & $7: 5 \times 10^{-15}$ \\
\hline
\end{tabular}

* “昭和45年 4 月 14 日受理

1. 正会員 工博 東北大学教授 工学部資源工学科

2. 正会員 岩手大学助教授 工学部資源工学科

3. 正会員 東北大学講師 I学部資源工学科

4. 正会員 東北大学大学院工学研究科学生

5. 栗田工業株式会社総合研究所
著者らの 1 人は $^{334)}$, 以前に硫酸㳯脱銅尾液中に含まれ る $\mathrm{Ni}^{2+}, \mathrm{Co}^{2+}$ イオンの回收について検討し, 多量の $\mathrm{Fe}^{2+}, \mathrm{Zn}^{2+}$ イオンなな゙から $\mathrm{Ni}^{2+}, \mathrm{Co}^{2+}$ イオンをザンセ 一下塩として選択的に沈殿させ，さらにNi，Co の相互 分離, ザンセートの回収などについて報告した。

本論文は，このようなザンセ一トの性質を利用して， 相当量の $\mathrm{Fe}^{2+}, \mathrm{Zn}^{2+}$ イオンが共存する鉱水中の $\mathrm{Cd}^{2+}$ イ オンの除去について検討したものである。

\section{2. 実験試料ならびに方法}

試料水として, $\mathrm{Cd}\left(\mathrm{NO}_{3}\right)_{2} \cdot 4 \mathrm{H}_{2} \mathrm{O}, \mathrm{ZnSO}_{4} \cdot 7 \mathrm{H}_{2} \mathrm{O}$ お了 び $\mathrm{FeSO}_{4} \cdot 7 \mathrm{H}_{2} \mathrm{O}$ の市販一級試薬を所定濃度に調整した 人工鉱水と中和处理前の某鉣山原水を用いた。ザンセー 卜としてアルキル基の炭素数が 1 5のものを常法によ り合成精製したものを用いた。

実験は試料水を $25 l$ あるいは $500 \mathrm{~m} l$ 容量のデンバー型 浮選機内に入れ所定量のザンセートを添加した後, 数分 間，空気混和しながら表面に形成したスカムを搔き出す 手順で行なつた。 $\mathrm{Cd}^{2+}$ イオンの除去率は, 処理液中の $\mathrm{Cd}^{2+}$ イオン濃度を原子吸光法により求めて算出した。 原子吸光分析装置は, 日本ジャーレルアッシュ製のもの を用いた。

\section{3. 実験結果および考察}

鉱水中に含まれる $\mathrm{Fe}^{2+}, \mathrm{Zn}^{2+}$ イオンからの $\mathrm{Cd}^{2+}$ イオ ンのザンセート塩としての選択的沈殿がぞの程度可能で めるかは, これら金属ザンセートの溶解度積の值から推 定することができる。これら金属ザンセートの溶解度積 は電導度法, 起電力法などにより求められて抢り ${ }^{\mathrm{b}}$, 第 2 表にその 1 例としてKakovsky が報告している值を示 す。また著者らの 1 人は以前に，KCN を用いた錯イオ ン滴定法によつて $\mathrm{Ag}^{+}, \mathrm{Ni}^{2+}$ 抢よび $\mathrm{Zn}^{2+}$ イオンのザン セート塩の溶解度積を求めたが゙，Cdザンセートの溶解 度積む同様に錯イオン滴定法によつて求められる。その

a) その他, $\mathrm{ABS}, \mathrm{Na}_{2} \mathrm{HPO}_{4}$ を使用して, $\mathrm{Cd}^{2+}$ イオンから選択的に浮選除 去する方法が報告されている。（中川雅直・甲斐田泰彦：日本化学会, 第23年会。1970年, 講演番号 19523)

b ) 南条・山崎は各種金属エチルザンセートの溶解度皘の種々の交献値を亲と めている5)。 
第 2 表 金属ザンセートの溶解度積

\begin{tabular}{|c|c|c|c|c|}
\hline \multirow{2}{*}{ Xanthats } & \multicolumn{2}{|r|}{ 献 } & 値 ${ }^{*}$ & \multirow{2}{*}{$\frac{\text { 実験値 }}{\text { Cd }}$} \\
\hline & $z n$ & $\mathrm{Cd}$ & $\mathrm{Fe}^{2 \cdot}$ & \\
\hline Methyl & - & - & $=$ & $4.10 \times 10^{12}$ \\
\hline Ethyl & $4.90 \times 10^{-9}$ & $2.60 \times 10^{-1 / 4}$ & 8. $\times 10^{-8}$ & $2.46 \times 10^{-14}$ \\
\hline $\begin{array}{l}n \text {-Propyl } \\
\text { iso-Propyl }\end{array}$ & $3.40 \times 10^{-10}$ & - & E & 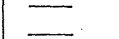 \\
\hline n-Buthyl & $3.7 \times 10^{-12}$ & $2.1 \times 10^{-16}$ & - & \\
\hline iso-Buthyl & $2.75 \times 10^{-11}$ & & - & $4.08 \times 10^{-17}$ \\
\hline n-Amyl & $1.55 \times 10^{-12}$ & $8.5 \times 10^{-18}$ & - & $1.55 \times 10^{-19}$ \\
\hline & & & & \\
\hline
\end{tabular}

結果を第 2 表の最右欄に示しているが Kakovskyの報告 している值とほぼ同様の值を得ている。同表より， Cd

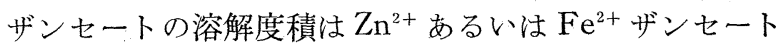
のそれよりも相当小さく, Cd ザンセートの選択的沈殿 が可能であることが予想される。また， Cd ザンセート の溶解度積はアルキル基の炭素鎖が長くなるにつれて小 さくなり，アルキル基の長いザンセートほど Cd ザンセ 一トの生成に効果的であることがわかる。

第 1 図は $\mathrm{Cd}^{2+} 1 \mathrm{mg} / l$ の鈗水に対してアルキル基の異 なる各種ザンセートを添加した場合のザンセート添加量 と処理残液の $\mathrm{Cd}^{2+}$ イオン濃度の関係について, 錯イオ ン滴定法により得られた溶解度積の值から計算した曲線 と $25 l$ 容量の浮選機で浮選した場合の測点を示したもの である。エチルザンセートの場合は計算值と実験值との 間にかなりのずれが認められるが，ブチルめるいはアミ ルザンセートを用いた場合は計算值と実験值が比較的よ く一致している。エチルザンセートの場合は $1 \mathrm{mg} / l$ の $\mathrm{Cd}^{2+}$ イオン濃度を $0.1 \mathrm{mg} / l$ まで低下させるには約 10 当 量のザンセートを必要とし( ), その使用は経済的に困難 であるが，ブチル基めるいはアミル基をもつ高級ザンセ 一トを用いると約 1.5 あるいは 1 当量で $\mathrm{Cd}^{2+}$ イオン濃 度を $0.1 \mathrm{mg} / l$ まで低下させることが可能であることがわ

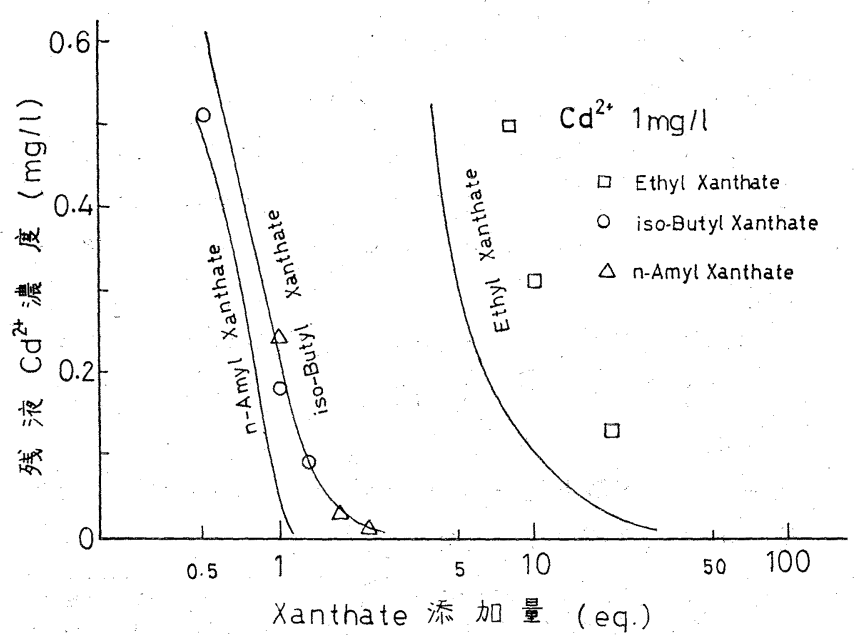

第1図 ザンセートによる $\mathrm{Cd}^{2+}$ の除去に抢よぼす炭化水素鎖の影響

c）メチルザソセートの場合は約 120 当量を必要とする。

$550\langle 36\rangle$
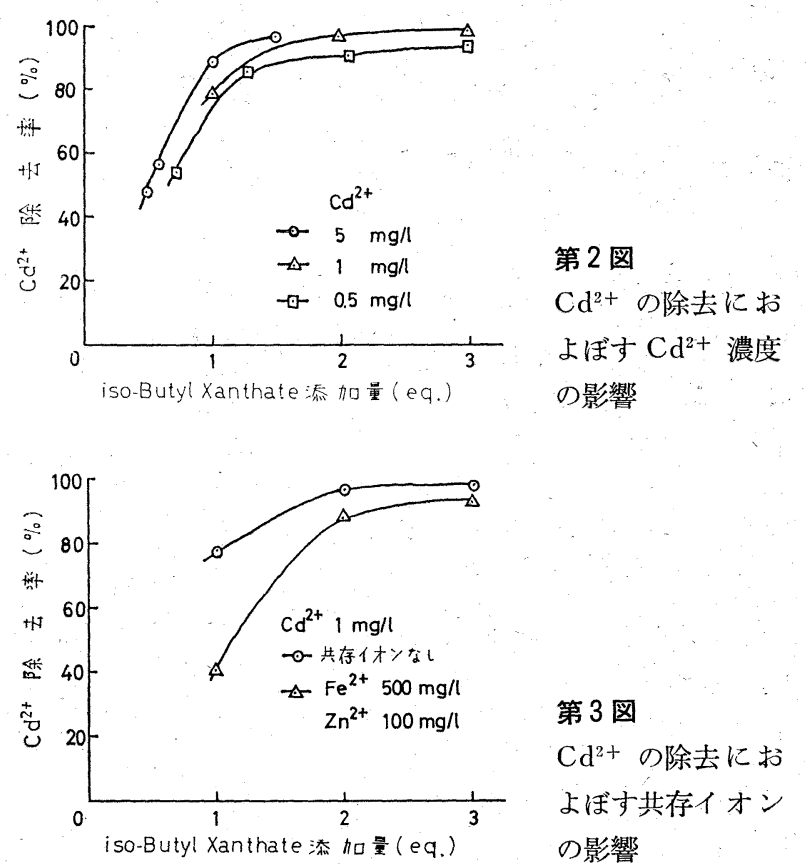

第 3 図

$\mathrm{Cd}^{2+}$ の除去にお よぼす共存イオン の影響

かる。

第 2 図は $\mathrm{Cd}^{2+}$ イオン濃度 $0.5,1$ および $5 \mathrm{mg} / l$ の溶 液に対して，25l容量の浮選機を用いて，イソブチルザ ンセートを加えて浮選した結果を示している。この図か ら $\mathrm{Cd}^{2+}$ イオン濃度が低下するにつれて, 同程度の $\mathrm{Cd}^{2+}$ イオン除去率を得るためには $\mathrm{Cd}^{2+}$ イオンに対するザン セートの添加量は当量として多く必要とすることがわか る。また, 廃水処理の立場からは処理残液の $\mathrm{Cd}^{2+}$. イ ン濃度を問題にしなければならないが，鉱水の $\mathrm{Cd}^{2+}$ イ オン濃度が $0.5,1$ および $5 \mathrm{mg} / l$ のものを $0.1 \mathrm{mg} / l$ ま で低下させるに必要なイソブチルザンセートの添加量は 溶解度積から $1.56 ， 1.28$ および 1.06 当量と計算され， この場合においても $\mathrm{Cd}^{2+}$ イオン濃度が低いほど $\mathrm{Cd}^{2+}$ イオンに対するザンセート添加量は理論量より多く必要 であることが理解される。

以上の実験は $\mathrm{Cd}^{2+}$ イオンのみを含む人工鉣水につい て行なつたものであるが，前述するように，実際の鉣水 中には通常多量の $\mathrm{Fe}^{2+}, \mathrm{Zn}^{2+}$ イオンが含有されている ので， Cdザンセートの生成におよぼすこれら 金属 イオンの共存の影響について検討した。

第 3 図は $\mathrm{Cd}^{2+} 1 \mathrm{mg} / l, \mathrm{Fe}^{2+} 500 \mathrm{mg} / l$ および $Z_{\mathrm{n}}{ }^{2+} 100 \mathrm{mg} / l$ を含む人工鉱水に対して,イソブチル ザンセートを用いて浮選した場合の結果である。同 図中に $\mathrm{Cd}^{2+}$ イオンのみを含む鉱水に対する結果も 比較のため示してあるが, $\mathrm{Fe}^{2+}$ および $\mathrm{Zn}^{2+}$ イオン の共存によつて $\mathrm{Cd}^{2+}$ イオンの除去率は低下してお り，とくにザンセートの添加量が少ないときに，そ

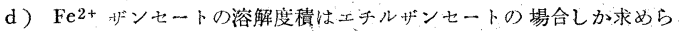

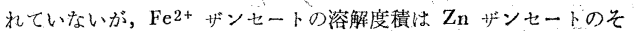
れよりさら飞大きいものと考えられている8)。 


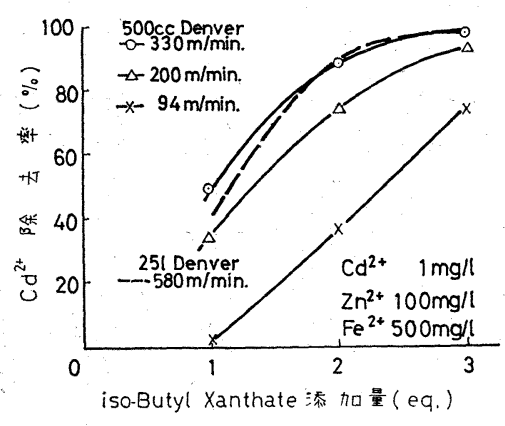

世第 4 図

$\mathrm{Cd}^{2+}$ の除去におよ

ぼす攪挥の強さの影

響

第 5 図 $\rightarrow$

各種ザンセートによ

るC d $\mathrm{d}^{2+}$ の除去

$\left(\mathrm{Cd}^{2+} 1 \mathrm{mg} / l, \mathrm{Zn}^{2+}\right.$

$100 \mathrm{mg} / l, \quad \mathrm{Fe}^{2+} 500 \mathrm{mg} / l$ )

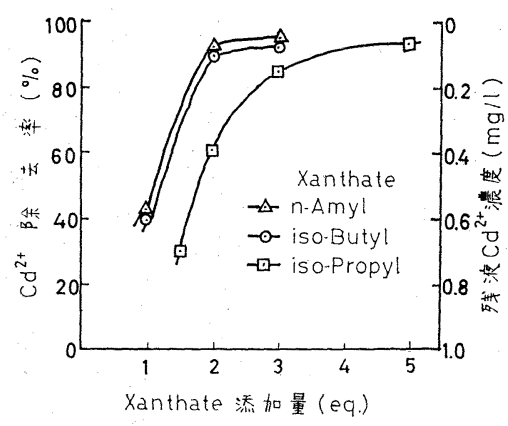

イオン濃度を $0.1 \mathrm{mg} / l$ 以下に下げることが可能である ことがわかる。

また，鉱水中にはしばしば $\mathrm{Fe}^{3+}$ イオンが含まれるが， $\mathrm{Fe}^{3+}$ イオンはザンセートを酸化分解するため, 鉱水中 の $\mathrm{Fe}^{3+}$ 、イオンをあらかじめ炭カル処理しg)，水酸化物 として沈殿除去することが必要である。

な㧍, 某釷山原水に対して, 炭カル処理し $\mathrm{Fe}^{3+}$ イオン を沈殿除去した後ザンセートを添加して浮選した結果, 人工鉱水に対する結果と比べてザンセートの必要量が若 干多くなつているが，ほぼ同様の結果が得られた。また 炭カル処理後の殿物を除去せず懸濁させたままで浮選し た場合に，それを除去した場合と比べて成績の大きな低 下は認められなかつた。

\section{4. 総括}

以上の結果を要約すると,

（1）カドミウムザンセートの溶解度積はアルキル基 の炭素鎖が長くなるにつれて小さくなり, $\mathrm{Cd}^{2+} 1 \mathrm{mg} / l$ を含む溶液中の $\mathrm{Cd}^{2+}$ イオン濃度を $0.1 \mathrm{mg} / \mathrm{l}$ まで低下さ せるにはエチルザンセートを用いるときは $\mathrm{Cd}^{2+}$ イオン に対して約10当量と非常に多く必要であるが，イソブチ ルあるいはアミルザンセートを用いるときは，それぞれ 約 1.5 あるいは 1 当量と少ない添加量で十分であること が溶解度積の值から計算され, 浮選実験とおいても, 計 算值と同心值を得た。

(2) 釷水中の $\mathrm{Cd}^{2+}$ イオン濃度が低くなるにつれて, $\mathrm{Cd}^{2+}$ イオン除去率は低下し, 同程度の $\mathrm{Cd}^{2+}$ イオンの除 去率を得るためには $\mathrm{Cd}^{2+}$ イオンに対するザンセートの 添加量を多く必要とすることがわかつた。

（3）鉱水中に $\mathrm{Zn}^{2+}$ あるいは $\mathrm{Fe}^{2+}$ イオンが共存する と $\mathrm{Cd}^{2+}$ イオンの除去率は低下し, とくにこの傾向はザ ンセートの添加量の少ないときに著しいことがわかつ た。

（4） Cd ザンセートの沈殿生成は浮選機内のエアー レーションにより著しく影響され, エアーレーションが 強いほど $\mathrm{Cd}$ ザンセートの除去率は増大寸る。この効果 は Cd ザンセートの疎水性によつて引き起される気泡を 介した凝集，すなわち “Pseudoflocculation”による粒 子成長の促進に帰因すると推察される。 
(5) $\mathrm{Cd}^{2+} 1 \mathrm{mg} / l, \mathrm{Zn}^{2+} 100 \mathrm{mg} / l, \mathrm{Fe}^{2+} 500 \mathrm{mg} / l$, を含む人工鉱水の $\mathrm{Cd}^{2+}$ イオン濃度を $0.1 \mathrm{mg} / l$ 以下にす るには，イソブチルめるいはイソアミルザンセートを $\mathrm{Cd}^{2+}$ イオンに対して約 $2 \sim 3$ 当量, イソプロピルザン セートを約 5 〜 6 当量必要であることがわかつた。

（6） $\mathrm{Fe}^{3+}$ イオンはザンセートを酸化分解するため に, 鉱水中に $\mathrm{Fe}^{3+}$ イオンを含む時は，炭カルにようて $\mathrm{Fe}^{3+}$ イオンを水酸化物として沈殿させる必要がある。某 鉱山原水について試験した結果, 炭カル処理後の殿物を” 除去七なくとも十分 $\mathrm{Cd}^{2+}$ イオンの浮上分離ができるこ とがわかつた。また，その場合の試験結果は，人工鈗水 に対するよりも若干多いザンセートを必要とするがほぼ 同様の結果が得られた。

以上, 鉱水中の $\mathrm{Cd}^{2+}$ イオンのザンセートによる浮上 分離についての実験結果を述べたが，Cd ザンセートと して消費されたザンセートの再生使用 ${ }^{\mathrm{h})}$, ならびに処理 残液中の過剩ザンセートの処理については今後検討せね ばならない問題であると考えられる。

また鉱水中の $\mathrm{Cu}^{2+}$ イオンのザンセートによる浮上分 離についても検討を行なつたが， $\mathrm{Cu}^{2+}$.イオンは炭素鎖 の短かいメチルあるいはエチルザンセートの添加によつ ても浮上させることができ, $\mathrm{Cd}^{2+}$ イオンから選択的に

h） Cd ザソセートに硫化ソーダを加えることによりて CdS が生成し，ザン セートイオンを遊離させることが可能である。
浮上分離することも可能である。

なお， $\mathrm{Au}, \mathrm{Ag}$ あるいは $\mathrm{Hg}$ などの貴金属イオンに対

しては，その濃度が極めてて低い場合でも，ザンセート塩

として沈殿させることが可能であり，これらの浮上分離

については今後検討して行きたいと考えている。

最後に, 本研究を行ならに当り, 有益な御助言を賜つ た東北大学選銨製鍊研究所 山崎太郎教授に深謝すると ともに，終始多大の御支援を賜つた栗田工業株式会社， 三菱金属鈗業株式会社ならびに同和鈗業株式会社の関係 各位にも深甚なる感謝の意を表するものである。

1) 吉村功: 科学, 38, 615, (1968)

\section{参 考 文 献}

2) 向井滋・古屋仲芳男 : 浮選, 38, 1, (1969)

3）大山正・下飯坂潤三・山崎太郎・馬場一郎・池内駿：日缸誌, 78, 391, (1962)

Tadashi Ohyama, Junzo Shimoiizaka, Taro Yamazaki, Ichiro Baba, Shun Ikeuchi: Bull. of Mining and Metallurgical Inst. of Japan, 1, 26, (1964)

4) 山崎太郎・下飯坂潤三・佐々木弘・大山正：日饩誌，79，97，(1963)

5）南条道夫・山崎太郎：東北大学選研桑報, 25, 66, (1969)

6) J.A. Kakovsky: Second International Congress of Surface Activity, IV, 225, Butterworths Scientific Pub. London (1957)

7）大山正・下飯坂潤三・目井進之助 - 大場章 - 山崎太郎 : 東北鉱山，4，22, (1957)

8) A. F. Taggart: "Handbook of Mineral Dressing" p. 12-08 John Wiley \& Sons Inc., New York (1950)

9) 大山正・下飯坂潤三・松岡功・加藤義重・高橋知行 : 東北鉣山， 13，64, (1966)

\title{
Study on the Removal of Cadmium Ion from Mine Water by
}

\section{Flotation Method Utilizing Xanthate as the Selective Precipitant}

\author{
by Junzo SHIMOIIZAKA, Shigeru HASEBE, Isao MATSUOKA, Tomoyuki TAKAHASHI \\ and Kazumasa YAMAMOTO
}

In mine water, a small amount of cadmium ion is sometimes contained together with appreciable amounts of ferrous and zinc ion.

The removal of cadmium ion from mine water has been studied by using xanthates as the selective precipitant.

The solubility product of cadmium xanthate reduces with increasing the chain length of an alkyl group. It is found that the amount of methyl, ethyl, butyl and amyl xanthate necessary for precipitating $90 \%$ of cadmium ion is about $120,10,1.5$ and 1 equivalent to cadmium ion involved in the solution, in the case of cadmium ion concentration of solution is $1 \mathrm{mg} / \mathrm{l}$.

The formation of the precipitate of cadmium xanthate depends very much on the condition of agitation of the solution in a Denver-type flotator used as reaction cell and the precipitate is effectively formed by vigorous agitation.

Owing to the strong hydrophobic property of cadmium xanthate, it is possible to remove the precipitate of cadmium xanthate from the solution by the flotation technique.

The romoval of cadmium as cadmium xanthate from the solution is prevented to some extent by the coexistence of zinc and ferrous ions.

When ferric ion is contained in mine water, it is necessary to remove the ferric ion before xanthation by leading it into ferric hydroxide with the addition of calcium carbonate, because xanthate ion is oxidized by ferric ion.

It is possible to reduce cadmium ion concentration below $0.1 \mathrm{mg} / l$ from an artificial mine water containing $1 \mathrm{mg} / \mathrm{l}$ of cadmium, $100 \mathrm{mg} / \mathrm{l}$ of zinc and $500 \mathrm{mg} / \mathrm{l}$ of ferrous ion, by the addition of $2 \sim 3$ equivalent of butyl and amyl xanthate, or $5 \sim 6$ equivalent of propyl xanthate to cadmium ion involved.

This result is proved by the actual mine water, too. 